\title{
Estradiol Enables Chronic Corticosterone to Inhibit Pulsatile Luteinizing Hormone Secretion and Suppress Kiss 1 Neuronal Activation in Female Mice
}

\author{
Michael J. Kreisman Richard B. McCosh Katherine Tian Christopher I. Song Kellie M. Breen \\ Department of Obstetrics, Gynecology and Reproductive Sciences, University of California, La Jolla, CA, USA
}

\section{Keywords}

Kisspeptin - Glucocorticoid receptor - Luteinizing hormone Arcuate nucleus - Gonadotropin-releasing hormone

\begin{abstract}
Introduction: Two common responses to stress include elevated circulating glucocorticoids and impaired luteinizing hormone (LH) secretion. We have previously shown that a chronic stress level of corticosterone can impair ovarian cyclicity in intact mice by preventing follicular-phase endocrine events. Objective: This study is aimed at investigating if corticosterone can disrupt LH pulses and whether estradiol is necessary for this inhibition. Methods: Our approach was to measure LH pulses prior to and following the administration of chronic corticosterone or cholesterol in ovariectomized (OVX) mice treated with or without estradiol, as well as assess changes in arcuate kisspeptin (Kiss1) neuronal activation, as determined by co-expression with c-Fos. Results: In OVX mice, a chronic $48 \mathrm{~h}$ elevation in corticosterone did not alter the pulsatile pattern of $\mathrm{LH}$. In contrast, corticosterone induced a robust suppression of pulsatile $\mathrm{LH}$ secretion in mice treated with estradiol. This suppression represented a decrease in pulse frequency without a change in amplitude. We
\end{abstract}

karger@karger.com

(c) 2019 S. Karger AG, Basel

www.karger.com/nen

Karger ${ }^{\prime \prime}=$ show that the majority of arcuate Kiss 1 neurons contain glucocorticoid receptor, revealing a potential site of corticosterone action. Although arcuate Kiss 1 and Tac2 gene expression did not change in response to corticosterone, arcuate Kiss 1 neuronal activation was significantly reduced by chronic corticosterone, but only in mice treated with estradiol. Conclusions: Collectively, these data demonstrate that chronic corticosterone inhibits LH pulse frequency and reduces Kiss1 neuronal activation in female mice, both in an estradiol-dependent manner. Our findings support the possibility that enhanced sensitivity to glucocorticoids, due to ovarian steroid milieu, may contribute to reproductive impairment associated with stress or pathophysiologic conditions of elevated glucocorticoids.

(c) 2019 S. Karger AG, Basel

\section{Introduction}

Stress profoundly alters the physiologic function through activation of a host of chemical and hormonal pathways, including activation of the hypothalamic-pituitary-adrenal axis and the release of glucocorticoids. An increase in circulating glucocorticoids is a common physio- 
logic response to many stressors and has been considered a potential mediator of reproductive suppression during stress. Evidence that a glucocorticoid receptor (GR) antagonist prevents the inhibition of gonadotropin secretion during stress in intact male rats and ovariectomized (OVX) female sheep treated with estradiol, supports a mediatory role of elevated glucocorticoids [1-3]. We have previously demonstrated that a chronic elevation of a stress-like level of corticosterone, the natural glucocorticoid in rodents, disrupts the ovulatory cycle of the female mouse [4]. Female mice exposed to elevated corticosterone remain in diestrus, a stage comparable to the early follicular phase in humans, suggesting that a suppression in luteinizing hormone (LH) secretion contributes to ovulatory cycle disruption. Indeed, increased circulating glucocorticoids, administered in the absence of stress, have been shown to impair pulsatile LH secretion during the follicular phase in women [5] or ewes [6], but the neuroendocrine mechanisms underlying reduced $\mathrm{LH}$ secretion remains unclear.

A large body of in vivo and in vitro work supports the hypothesis that glucocorticoids can act centrally and at the pituitary gland to inhibit LH secretion. Glucocorticoids can suppress pituitary responsiveness to gonadotropin-releasing hormone $(\mathrm{GnRH})$ and lower LH pulse amplitude in numerous species and under a variety of gonadal steroid regimens [7-14], which suggests a pituitary mechanism. On the contrary, data from castrated rhesus monkeys demonstrate that the glucocorticoid-induced suppression of $\mathrm{LH}$ can be reversed by exogenous $\mathrm{GnRH}$, indicating a central mechanism of suppression [15]. A hypothalamic mechanism is also supported by data in which glucocorticoids alter LH pulse frequency, which is taken as evidence for an action upon the central GnRH pulse generator. For example, elevated corticosterone decreases the frequency of both GnRH and LH pulses in ovary-intact ewes during the follicular phase of the estrous cycle or in OVX ewes treated with estradiol and progesterone to simulate a follicular phase $[6,16]$. Interestingly, corticosterone does not reduce GnRH or LH pulse frequency in OVX ewes devoid of gonadal steroids, indicating that this mode of LH suppression is dependent on ovarian steroid milieu [7]. Scant evidence for the presence of either GR or ovarian steroid receptors within GnRH neurons themselves [17-19] points to an afferent cell type expressing kisspeptin (encoded by the Kiss1 gene). Kisspeptin neurons in the arcuate nucleus also contain neurokinin $\mathrm{B}$ and dynorphin and are thus termed KNDy cells [20,21]. Based on abundant anatomical, pharmacological, and electrophysiological data in rats, goats, and sheep, this neuron population was hypothesized to form the GnRH pulse generator [21-25]. More recently, arcuate kisspeptin neurons were confirmed to be the GnRH pulse generator in mice [26]. Thus, this cell population may form the pulse generator in numerous species. Importantly, KNDy cells express estradiol receptor alpha $(\mathrm{ER} \alpha)[27,28]$ and in sheep, they also express GR [29]. Therefore, this cell population may be a cellular mediator of the suppressive effect of elevated glucocorticoids on $\mathrm{GnRH}$ and LH pulsatile secretion.

The aim of this study was to test the hypothesis that elevated corticosterone impairs ovarian cyclicity in females by inhibiting the $\mathrm{GnRH}$ pulse generator. For this purpose, we took advantage of our ability to monitor robust pulsatile LH secretion in female mice under OVX conditions, when the release of $\mathrm{LH}$ is unrestrained by gonadal steroids. As the results of our initial experiment implicated ovarian steroids as a potential factor influencing the response to corticosterone, subsequent experiments utilized a low physiological estradiol treatment, approximating a diestrus level based on uterine weight, to test the effect of this ovarian steroid in modulating the response to chronic corticosterone. We pursued experiments to determine whether the reduction in pulsatile LH was mediated by a diminished gonadotrope responsiveness to GnRH or suppression of kisspeptin-containing cells within the arcuate nucleus.

\section{Materials and Methods}

\section{Animals}

Wild-type C57BL/6 (Envigo; Experiments 1-3 and 5A), Kiss1 CreGFP (Experiment 4), or Kiss1hrGFP (Experiment 5B) mice were housed 2 per cage under standard conditions under a 12-h light, 12-h dark cycle with lights on at $06.00 \mathrm{~h}$. Kiss1CreGFP [30] transgenic mice express Cre-recombinase driven by Kiss1 regulatory elements which allows Kiss1 neurons to be identified by Cre-mediated expression of green fluorescent protein (GFP). KisslhrGFP [31] transgenic mice express humanized recombinant GFP (hrGFP) driven by Kiss1 regulatory elements which allows Kiss 1 expression to be assessed with the GFP reporter. Animals had ad libitum access to water and Harlan irradiated chow \#2920X at a University of California, San Diego vivarium. OVX was performed aseptically under isoflurane anesthesia on animals 8-14 week old, unless otherwise stated. All surgeries and serial blood samplings were performed between 08.00 and $12.00 \mathrm{~h}$. All animal procedures were performed in accordance with the University of California, San Diego Institutional Animal Care and Use Committee regulations and were performed in accordance with the National Institutes of Health guidelines for the care and use of research animals.

\section{Experimental Details}

Experiment 1: Does Chronic Corticosterone Reduce Pulsatile LH Secretion?

C57BL/ 6 mice were handled daily for 5 weeks prior to blood collection to acclimatize animals to the serial tail-bleed sampling required for pulsatile $\mathrm{LH}$ measurement, as published previously 
$[32,33]$. Mice were OVX and implanted subcutaneously with a silastic capsule containing oil (Fig. 1a for experimental details). After 10 days, blood samples from the tail vein were collected with a pipette every 6 min for two 90 -min intervals, pre: -1.5 to $0 \mathrm{~h}$ or post: $46.5-48 \mathrm{~h}$, relative to the subcutaneous implantation of a pellet containing either cholesterol or corticosterone $(n=3$ / group) while briefly exposed to isoflurane anesthesia. Cholesterol or corticosterone-releasing pellets were manufactured in our laboratory as described previously [4], by coating siliconefilled (Liquid Nails, Butler County, PA, USA) Silastic tubing of $1.0 \mathrm{~cm}$ length $(0.040$ in. I.D. $\times 0.085$ in. O.D.) with molten steroid, as per Meyer et al. [34]. Pilot studies were conducted to establish an effective corticosterone pellet composition (25 mg corticosterone: $25 \mathrm{mg}$ cholesterol; Sigma, St. Louis, MO, USA) that would produce a continuous elevation in circulating corticosterone which would mimic the peak level of endogenous corticosterone we observe in response to isolation/restraint stress in female mice [35]. Note, the unchanging corticosterone level produced in the present study likely exceeds the duration of an endogenous corticosterone response to acute stress. An equivalent weight of pure cholesterol $(50 \mathrm{mg}$ ) was used to manufacture vehicle pellets for implantation in control animals. Tail blood (15 $\mu \mathrm{L}$ ) was collected 2 days following implantation at $07.00 \mathrm{~h}$, prior to serial sampling, for analysis of circulating corticosterone levels in OVX animals.

Experiment 2: Does Estradiol Enable Chronic Corticosterone to Inhibit Pulsatile LH Secretion?

Estradiol Implants. Silastic tubing (0.125 in. inner diameter $\times 0.078$ in. outer diameter, DOW, Midland, MI, USA) was cut to $2 \mathrm{~cm}$ in length. One end of the tubing was sealed with $0.3 \mathrm{~cm}$ silicon allowed to cure overnight. Next, $1.4 \mathrm{~cm}$ of the tubing was filled with sesame oil (0 ng control group, MilliporeSigma) or 20,40, or 100 ng of 17- $\beta$ estradiol (MilliporeSigma) dissolved in sesame oil. The open end of the tubing was then sealed with $0.3 \mathrm{~cm}$ silicon and allowed to cure. The implants were submerged in sterile saline for 14-18 h prior to surgery.

OVX + E Treatment. Mice were OVX and implanted subcutaneously with a silastic capsule containing $0,20,40$ or $100 \mathrm{ng}$ estradiol ( $n=6-17$ /group for 0 or $100 \mathrm{ng}$; $n=4$ /group for 20 or $40 \mathrm{ng}$ estradiol). LH pulse frequency and body weight were measured 10 days post OVX. Tail blood $(15 \mu \mathrm{L})$ was collected at $17.00 \mathrm{~h}$ and the following day at $07.00 \mathrm{~h}$ (11-12 days post OVX) to evaluate the diurnal rise of corticosterone which is observed in intact females, but not in OVX mice [36]. Corticosterone values were compared to values in regularly cycling females in diestrus, as determined by vaginal lavage. Finally, mice were euthanized, and the uterus was dissected and weighed (12 days post OVX). Uterine and body weight values were compared to a diestrus control group, which received an oil capsule during a sham OVX procedure to account for surgical influences 10 days prior to assessment (animal was anesthetized and the ovaries exteriorized through lumbar laparotomy prior to routine suture and staple closure).

To test the effect of estradiol on the response to corticosterone, mice were OVX and implanted with $100 \mathrm{ng}$ estradiol, hereafter referred to as OVX $+\mathrm{E}$. Ten days following corticosterone or cholesterol ( $n=8-9 /$ group), blood samples were collected for measurement of pulsatile LH and corticosterone, as in Experiment 1 (Fig. 1b).

CORT Requires Estradiol to Slow LH

Pulse Frequency

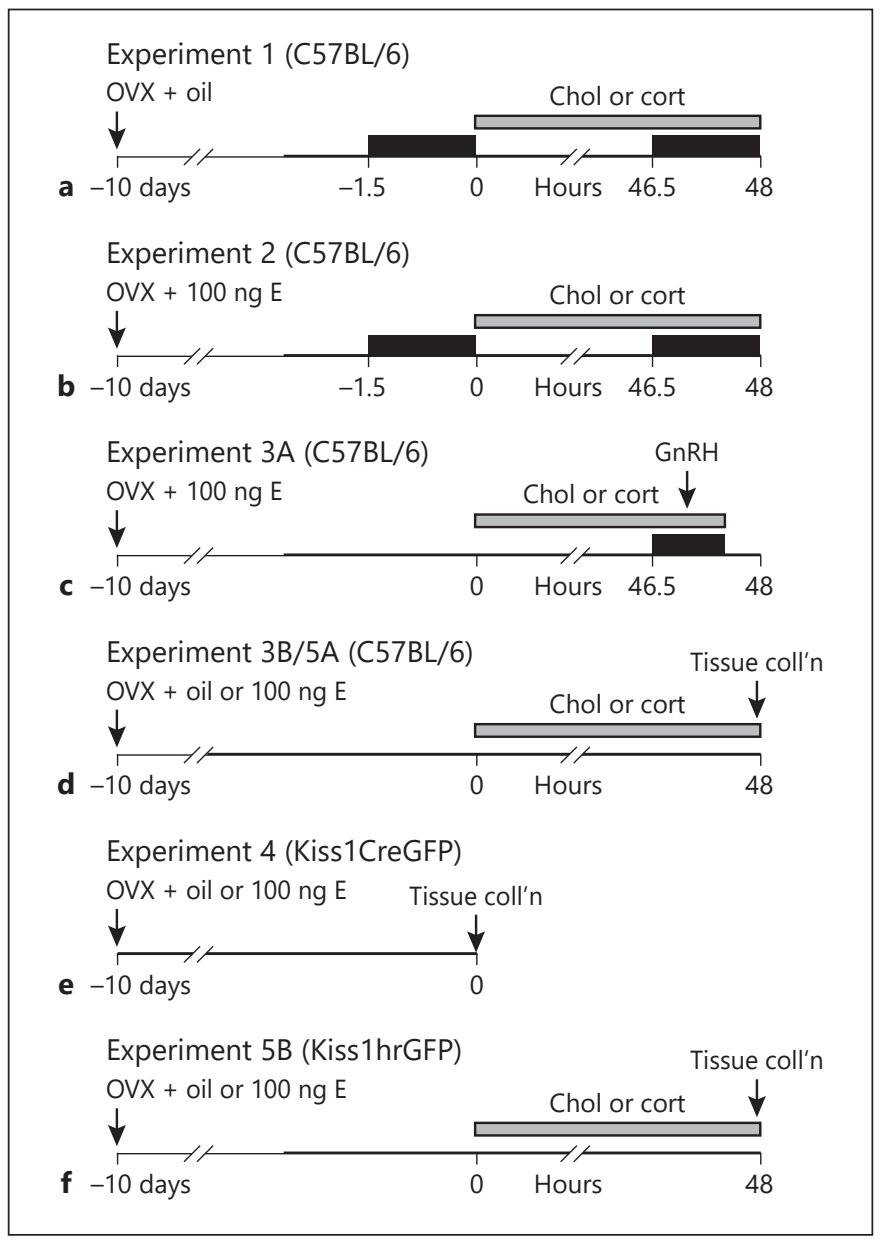

Fig. 1. a-f Animal strains and experimental designs. Time is depicted in hours relative to the implantation of corticosterone (Cort) or cholesterol (Chol), indicated by the dashed horizontal bar. Time of frequent sampling for LH analysis is identified by the black boxes. As indicated by the arrow, OVX and implantation with oil or estradiol (E) implant occurred 10 days prior to experimentation. GnRH $(800 \mathrm{ng} / \mathrm{kg}$, ip) was administered $\sim 47 \mathrm{~h}$ after corticosterone or cholesterol in Experiment 3A. Time of tissue collection is indicated for Experiment 3B/5A (fresh frozen) and Experiment 4/5B (fixed). OVX, ovariectomized; GnRH, gonadotropin-releasing hormone.

Experiment 3: Does Estradiol Enable Chronic

Corticosterone-Induced Suppression of Gonadotrope

Responsiveness to GnRH or Pituitary Gene Expression?

Pituitary Responsiveness to GnRH (3A). Ten days after OVX + E, mice were implanted with cholesterol or corticosterone $(n=8 /$ group). Approximately $48 \mathrm{~h}$ later, tail blood for measurement of $\mathrm{LH}$ was collected every $6 \mathrm{~min}$ for $24 \mathrm{~min}$ prior to and $30 \mathrm{~min}$ following intraperitoneal (ip) injection with $\mathrm{GnRH}(800 \mathrm{ng} / \mathrm{kg}$, MilliporeSigma, St. Louis, MO, USA; Fig. 1c). Serial samples were collected to observe the $\mathrm{LH}$ pulse pattern prior to $\mathrm{GnRH}$ administration. The response to $\mathrm{GnRH}$ was calculated as the difference in $\mathrm{LH}$ concentration at time 0 compared to the peak LH value occurring within $12 \mathrm{~min}$ of $\mathrm{GnRH}$ (i.e., the higher value at either the 6- or 12-min time point).

Neuroendocrinology 2020;110:501-516 
Table 1. Primary antibodies

\begin{tabular}{|c|c|c|c|c|c|c|}
\hline $\begin{array}{l}\text { Peptide/ } \\
\text { protein target }\end{array}$ & $\begin{array}{l}\text { Antigen sequence (if } \\
\text { known) }\end{array}$ & $\begin{array}{l}\text { Name of } \\
\text { antibody }\end{array}$ & $\begin{array}{l}\text { Manufacturer, } \\
\text { Catalog \# } \\
\text { and/or name } \\
\text { of individual } \\
\text { providing the } \\
\text { antibody }\end{array}$ & $\begin{array}{l}\text { Species raised } \\
\text { in; monoclonal } \\
\text { or polyclonal }\end{array}$ & $\begin{array}{l}\text { Dilution } \\
\text { used }\end{array}$ & RRID \\
\hline $\begin{array}{l}\text { Glucocorticoid } \\
\text { receptor }\end{array}$ & $\begin{array}{l}\text { Synthetic sequence } \\
\text { from human GR: } \\
\text { D(346) Q K P I F N V } \\
\text { I P P I P V G S E N W } \\
\text { N R C (367) }\end{array}$ & $\begin{array}{l}\text { Glucocorticoid } \\
\text { receptor polyclonal } \\
\text { antibody }\end{array}$ & $\begin{array}{l}\text { Thermo Fisher } \\
\text { Scientific Cat\# } \\
\text { PA1-511A }\end{array}$ & $\begin{array}{l}\text { Rabbit; } \\
\text { polyclonal }\end{array}$ & $1: 500$ & AB_2236340 \\
\hline $\begin{array}{l}\text { Green } \\
\text { fluorescent } \\
\text { protein }\end{array}$ & $\begin{array}{l}\text { GFP from } \\
\text { jellyfish } \\
\text { (Aequorea Victoria) }\end{array}$ & $\begin{array}{l}\text { GFP polyclonal } \\
\text { antibody, Alexa } \\
\text { Fluor } 488\end{array}$ & $\begin{array}{l}\text { Thermo Fisher } \\
\text { Scientific Cat\# } \\
\text { A-21311 }\end{array}$ & $\begin{array}{l}\text { Rabbit; } \\
\text { polyclonal }\end{array}$ & $1: 1,000$ & AB_221477 \\
\hline
\end{tabular}

Pituitary Gene Expression (3B). Ten days after OVX or OVX + $\mathrm{E}$, animals received either a cholesterol or corticosterone implant ( $n=7-10$ /group). Approximately $48 \mathrm{~h}$ later, animals were euthanized under isoflurane via rapid decapitation. The brain and pituitary gland were immediately frozen on dry ice, and stored at $-80^{\circ} \mathrm{C}$ for RNA extraction and gene expression analysis. Tissues were collected from one cohort of mice and analyzed in Experiment 3B (pituitary) and Experiment 5A (brain).

Experiment 4: Is GR Expressed in KNDy Neurons?

Ten days after OVX or OVX + E, Kiss1CreGFP mice (8-38 week old, $n=4$ /group) were euthanized with an overdose of pentobarbital (Fatal Plus, MWI Animal Health, Boise, ID, USA) and perfused by cardiac puncture with $4 \%$ paraformaldehyde in phosphate-buffer saline (PBS). Once removed, brains were stored overnight in $4 \%$ paraformaldehyde and then transferred to $30 \%$ sucrose in phosphate buffer (PB) for at least 1 day.

Experiment 5: Does Chronic Corticosterone Inhibit KNDy Gene Expression or KNDy Neuron Activity?

KNDy Gene Expression (5A). Ten days after OVX or OVX $+\mathrm{E}$, mice were implanted with cholesterol or corticosterone $(n=6-10 /$ group) and brains were collected $48 \mathrm{~h}$ later, according to Experiment 3B.

$c$-Fos in KNDy Neurons (5B). Ten days after OVX or OVX + E, Kiss1hrGFP mice were implanted with cholesterol or corticosterone ( $n=5-7 /$ group). Approximately $48 \mathrm{~h}$ later, animals were perfused by cardiac puncture and fixed brain tissue was collected as in Experiment 4.

RNA Isolation and Gene Expression Analysis

RNA was extracted from individual pituitaries via Trizol reagent (Life Technologies - Ambion, Waltham, MA, USA) per manufacturer's directions. To isolate RNA from the arcuate nucleus, brains were sectioned coronally $(250 \mu \mathrm{m})$ on a cryostat at $-10^{\circ} \mathrm{C}$. Sections were collected from -1.22 to $-2.54 \mathrm{~mm}$ from breg- ma, according to a mouse brain atlas [37]. Semicircular micropunches, $2 \mathrm{~mm}$ in diameter, which encompassed the whole arcuate nucleus were collected and stored at $-80^{\circ} \mathrm{C}$. RNA was isolated from arcuate punches using the RNAqueous Micro Kit (Life Technologies - Ambion), per manufacturer's instructions.

Following isolation, DNA contamination was removed with DNA-free DNase treatment (Life Technologies - Ambion) and RNA was quantified by nanodrop. RNA $(1 \mu \mathrm{g})$ was reverse transcribed using the iScript Complementary DNA synthesis kit (Bio-RAD, Hercules, CA, USA). For quantitative polymerase chain reaction, complementary DNA and gene-specific primers were loaded according to online supplementary Table 1 (see www.karger.com/doi/10.1159/000502978 for all online suppl. material), along with SYBR green (Bio-RAD). Data were analyzed using the comparative cycle threshold $\left({ }^{\Delta \Delta} \mathrm{Ct}\right)$ method using Gapdh as a reference gene, as it displayed transcriptional stability across samples [38].

\section{Immunohistochemistry}

Immunohistochemistry for GFP and GR

Fixed tissue was sectioned $(30 \mu \mathrm{m})$ on a cryostat in 3 series and stored in cryoprotectant solution (30\% ethylene glycol, $30 \%$ sucrose, $1 \%$ polyvinyl pyrrolidone in $\mathrm{PB}$ ) at $-20{ }^{\circ} \mathrm{C}$ until processed for immunohistochemistry (IHC). The following steps were performed at room temperature with gentle agitation unless noted otherwise. Sections from one series, encompassing the entire arcuate nucleus, were processed from each animal. Tissue was rinsed in PBS with $0.1 \%$ Triton X-100 (PBST) 6 times, for 10 min each. Antigen retrieval was performed by incubating tissue in boiling Citra Buffer (Fisher Scientific, Waltham, MA, USA) for $10 \mathrm{~min}$, twice. Tissue was rinsed ( 4 times, 5 min each with PBST; standard rinsing step, unless noted otherwise) and incubated in a blocking solution containing 5\% normal goat serum (NGS; Jackson Labs, West Grove, PA, USA) containing 0.1\% BSA in PBST, for $1 \mathrm{~h}$. Tissue was then incubated in rabbit anti-GR (1:500, Thermo PA1511A; Table 1) in blocking solution for $2 \mathrm{~h}$ at room temperature 
followed by $18 \mathrm{~h}$ at $4{ }^{\circ} \mathrm{C}$. The next day, tissue was rinsed, then incubated in goat anti-rabbit conjugated to Alexa 594 (1:300, Life A-11012) in blocking solution for $2 \mathrm{~h}$ and rinsed again. Tissue was then incubated in rabbit anti-GFP conjugated to Alexa 488 (1:1,000, Life A-21311; Table 1) in blocking solution for $18 \mathrm{~h}$ at $4{ }^{\circ} \mathrm{C}$. Finally, tissue was rinsed, mounted on Superfrost slides (Fisher Scientific), coverslipped with gelvatol [39], and stored at $4{ }^{\circ} \mathrm{C}$ until microscopy. Because the antiserum raised against GFP was directly conjugated to the fluorophore (Alexa 488), and it was used after the detection of GR, no cross reactivity is expected, though the primary antisera were raised in the same species. Moreover, the expected cellular distribution of these antigens and the staining pattern (GR in the nucleus and GFP throughout the cell) further demonstrates a lack of cross reactivity. This GR antiserum has been used extensively for the detection of GR in mouse neural tissue $[40,41]$; in our laboratory, pre-adsorption with recombinant GR resulted in no specific staining (online suppl. Fig. 1a). No specific staining was observed when the GFP antisera was applied to wild-type mouse neural tissue (online suppl. Fig. 1b).

\section{IHC for GFP and c-Fos}

One series of $30 \mu \mathrm{m}$ sections, encompassing the entire arcuate nucleus, was processed for each animal. The following steps were performed at room temperature with gentle agitation, unless noted otherwise. Tissue was rinsed in PB, 12 times for $15 \mathrm{~min}$, and incubated overnight at $4{ }^{\circ} \mathrm{C}$. The next day, tissue was rinsed 6 times in $\mathrm{PB}$ and then 6 times in PBS, for 5 min each (the following rinsing steps were performed in PBS). Antigen retrieval was performed by incubating tissue in boiling Citra Buffer for $10 \mathrm{~min}$, twice. Tissue was rinsed and incubated in $0.3 \%$ hydrogen peroxide in PBS for 10 min. Next, tissue was rinsed and then incubated in blocking solution, containing PBS with $0.4 \%$ Triton X-100 and 4\% NGS, for $1 \mathrm{~h}$. Tissue was then incubated in rabbit anti-c-Fos (1:15,000, MilliporeSigma, ABE457; Table 1) in blocking solution for $18 \mathrm{~h}$ at $4{ }^{\circ} \mathrm{C}$. The next day tissue was rinsed and then incubated with biotinylated goat anti-rabbit antisera in blocking solution (1:500, Vector Laboratories, BA1000, Burlingame, CA, USA) for $1 \mathrm{~h}$. Next, tissue was rinsed and then signal was amplified with Vectastain Elite ABC Kit (1:500, Vector Laboratories, PK-6100), in PBS for $1 \mathrm{~h}$. Tissue was rinsed and then incubated with biotinylated tyramine (1:250, Perkin Elmer Inc., SAT70001EA, Shelton, CT, USA) in PBS containing $0.003 \%$ hydrogen peroxide for $10 \mathrm{~min}$. Tissue was rinsed and incubated with streptavidin conjugated to Alexa 647 (1:100, Life S32357) in PBS. Tissue was rinsed and incubated in blocking solution for $1 \mathrm{~h}$ and incubated in rabbit anti-GFP conjugated to Alexa 488 $\left(1: 1,000\right.$, Life A-21311) in blocking solution for $18 \mathrm{~h}$ at $4{ }^{\circ} \mathrm{C}$. Finally, tissue was rinsed, mounted on Superfrost slides, coverslipped with gelvatol [39], and stored at $4{ }^{\circ} \mathrm{C}$ until microscopy. Omission of the c-Fos antisera resulted in no specific staining in the arcuate or any other region examined (online suppl. Fig. 1c). As described in the previous section, the anti-GFP antisera was conjugated directly to the fluorophore (Alexa 488) which obviates the need for a secondary antiserum which could have cross-reacted with the other primary antibody. Additionally, the c-Fos antiserum was used at a sufficiently low concentration that omission of the tyramide step prevented the detection of antigen (online suppl. Fig. 1d).

\section{Imaging}

Imaging was performed with a Nikon Ti2-E inverted microscope with DS-Qi2 monochrome CMOS camera controlled with
NIS elements. At least 2 hemi-sections from each of 3 arcuate regions were selected for analysis (i.e., rostral, middle, and caudal). Within each region of the arcuate, the total number of GFP cells and the percentage of GFP cells that contained GR (Experiment 4) or the percentage of GFP cells that contained c-Fos (Experiment 5 ) were determined in each hemi-section. The mean \pm SEM number of GFP cells per hemi-section or mean percentage of GFP cells that contained either GR (Experiment 4) or c-Fos (Experiment 5) is reported. Comparisons were then made between treatment groups (within region) with animal as the experimental unit. All cell counting was done by an observer blinded to treatment group using Image J software [42].

Ultrasensitive Mouse LH Enzyme-Linked Immunosorbent Assay

Whole blood $(3 \mu \mathrm{L})$ samples for the measurement of $\mathrm{LH}$ were immediately diluted (1:20) into $57 \mu \mathrm{L}$ of assay buffer, mixed, and placed on ice until storage at $-20^{\circ} \mathrm{C}$ [33]. $\mathrm{LH}$ was measured in singleton by in-house enzyme-linked immunosorbent assay at the University of Virginia Ligand Assay Core, based on a method and reagents published in Steyn et al. [43]. The limit of quantitation (functional sensitivity) is defined as the lowest concentration that demonstrates accuracy within $20 \%$ of expected values and intra assay coefficient of variation $(\% \mathrm{CV})<20 \%$ and was determined by serial dilutions of a defined sample pool. Functional sensitivity was $0.320 \mathrm{ng} / \mathrm{mL}$. Intraand interassay \%CVs were 2.3 and $7.0 \%$, respectively.

\section{Corticosterone Enzyme-Linked Immunosorbent Assay}

Blood was centrifuged at 5,000 rpm for $15 \mathrm{~min}$ and serum was isolated and stored at $-20^{\circ} \mathrm{C}$ until assayed. Serum $(4 \mu \mathrm{L})$ was diluted 1:100-1:400 and assayed using DetectX Corticosterone EIA kit (K014; Arbor Assays, Ann Arbor, MI, USA), per Luo et al. [4]. Intra-assay and interassay \%CVs were 1.8 and $4.4 \%$, respectively. Assay sensitivity was $18.6 \mathrm{pg} / \mathrm{mL}$.

\section{Data Analysis}

LH Pulse Analysis

Detection of an LH pulse was based on 3 criteria, proposed by Goodman and Karsch [44]: (1) the pulse peak must be within 3 consecutive samples (i.e., $18 \mathrm{~min}$ ) from the preceding nadir, (2) the amplitude must be greater than the sensitivity of the assay, and (3) the amplitude must also be 2 SDs above the variability of the assay. Average values for pulse frequency, mean LH, and pulse amplitude were calculated across the pre- and post-periods. Pulse frequency was defined as the number of pulses in each 90 -min period. Mean LH was calculated by averaging all LH values in each sampling period. Pulse amplitude was calculated as the difference from the pulse peak to the preceding nadir, and an average pulse amplitude value for each animal during the pre and post sampling period was determined. Note, 2 of 8 animals did not demonstrate detectable pulses following corticosterone and were excluded from the assessment of pulse amplitude.

Two-way analysis of variance (ANOVA) followed by Tukey's honestly significant difference test was used to determine significant differences across time (pre vs. post, AM vs. PM) or treatments or groups (oil vs. estradiol, cholesterol vs. corticosterone), and to identify significant interactions between variables: $\mathrm{LH}$ characteristics, mean corticosterone, ${ }^{\Delta \Delta} \mathrm{Ct}$ relative quantity, and co-localization of c-Fos/Kiss1 values. One-way ANOVA followed by Tukey's honestly significant difference test was used to determine significant differences in estradiol response measures: uter- 

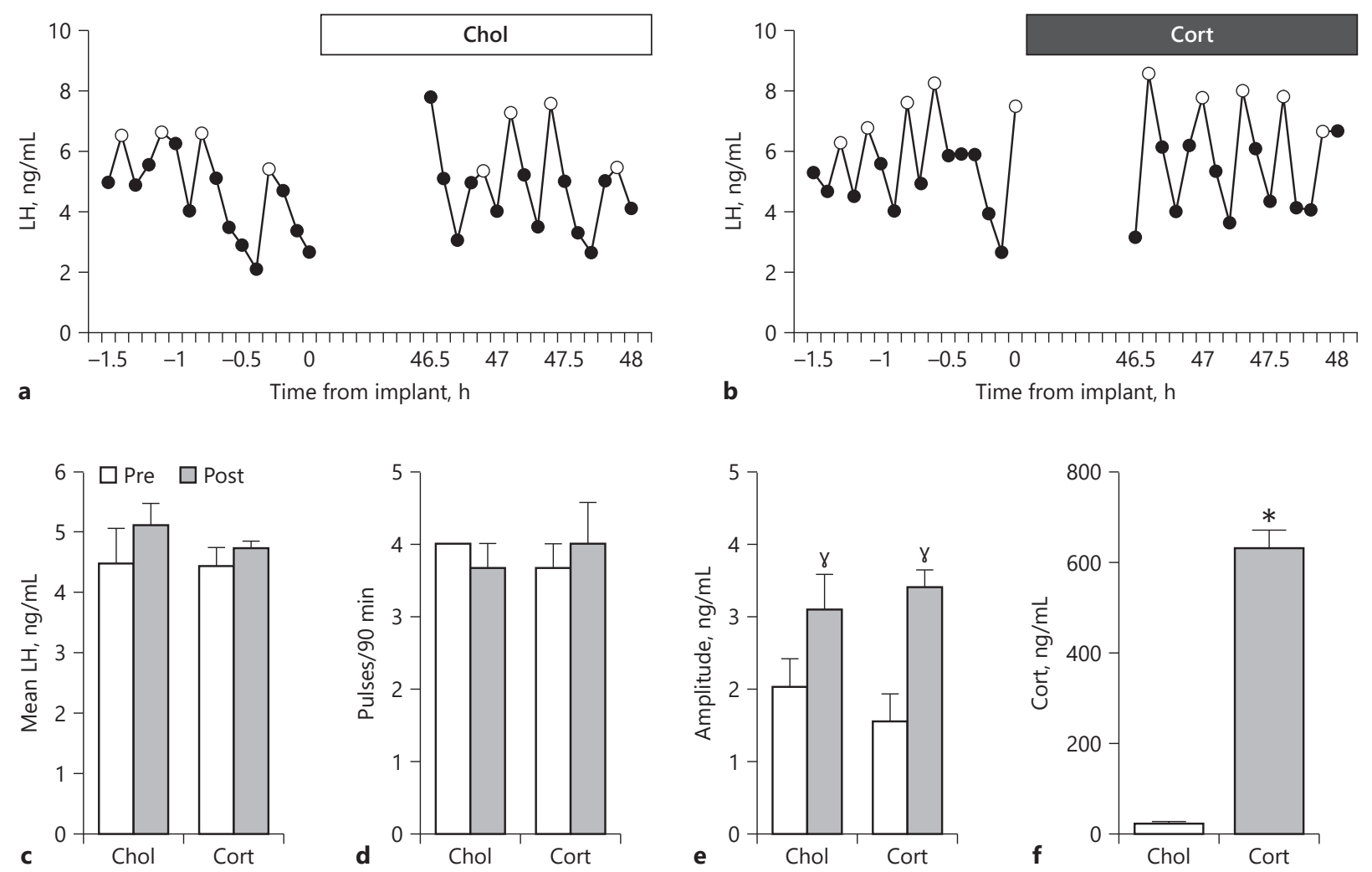

Fig. 2. Chronic corticosterone does not disrupt LH pulses in OVX mice. Pattern of pulsatile LH secretion in a representative OVX mouse treated with either cholesterol (a, chol) or corticosterone (b, cort) via a subcutaneous implant, as depicted by the bar at the top of each panel. LH pulses are identified by open circles. Values (mean \pm SEM) for mean LH (c), pulse frequency (d), and pulse amplitude (e) were calculated across time (Pre, white bars vs. Post,

ine weight, weight gain, or pulse frequency. Values for c-Fos/Kiss1 were square-root transformed prior to analysis to conform with the assumptions for ANOVA, as the non-transformed values were not normally distributed and the SDs were not homogeneous. Student $t$ test was used to determine differences in mean corticosterone, $\mathrm{LH}$ response to $\mathrm{GnRH}$, or co-localization of GR/Kiss1. Values are expressed as mean \pm SEM. All statistical analyses were performed using JMP 10.0.0 (SAS Institute, Cary, NC, USA) and statistical significance was defined as $p<0.05$.

\section{Results}

Experiment 1: Does Chronic Corticosterone Reduce Pulsatile LH Secretion?

Representative LH pulse profiles collected from OVX mice prior to ( -1.5 to $0 \mathrm{~h}$, pre) and $48 \mathrm{~h}$ following (46.5- grey bars) in each treatment group and analyzed ( $n=3$ mice/ group). No significant time $\times$ treatment interactions were identified. $\gamma$, effect of time $(p<0.05)$. $\mathbf{f}$ Serum corticosterone concentrations (mean \pm SEM) in mice prior to the serial sampling which occurred 2 days following implantation ( $n=4-5$ per group). * Effect of treatment $(p<0.05)$. LH, luteinizing hormone.

$48 \mathrm{~h}$, post) implantation with cholesterol (a, chol) or corticosterone (b, cort), are shown in Figure 2. During the pre-implant period in both groups, mean $\mathrm{LH}$ averaged $4.5 \mathrm{ng} / \mathrm{mL}$ and $\mathrm{LH}$ pulse frequency averaged 4 pulses/90 min (Fig. 2c, d). Regardless of treatment, values for mean $\mathrm{LH}$ and $\mathrm{LH}$ pulse frequency did not significantly differ across pre and post periods. Although LH pulse amplitude did not significantly differ between groups in the pre period, amplitude was significantly increased in the post period in both groups (Fig. 2e, pre vs. post, $p<0.05$ ), likely due to increased time from OVX. Circulating levels of corticosterone were significantly elevated in animals treated with corticosterone compared to controls (Fig. $2 \mathrm{f}, 23 \pm 3$ vs. $632 \pm 38 \mathrm{ng} / \mathrm{mL}$, chol vs. cort, $p<0.05)$. 
Fig. 3. Assessment of OVX + E model. Mean ( \pm SEM) uterine weight (a) or weight gain (b) in mice OVX and replaced with an implant containing $0,20,40$, or $100 \mathrm{ng}$ of estradiol, compared to a diestrus control group or a control group that were sham OVX and replaced with an oil implant. c Mean $( \pm$ SEM) LH pulse frequency measured in OVX mice replaced with an implant containing $0,20,40$, or $100 \mathrm{ng}$ of estradiol. d Mean ( \pm SEM) serum corticosterone concentrations measured at 07.00 (a.m.) and 17.00 h (p.m.) following OVX plus 0 ng estradiol (OVX) or 100 ng estradiol $(\mathrm{OVX}+\mathrm{E})$ and compared to diestrus controls. Unique letters signify significant differences between values $(p<0.05)$.
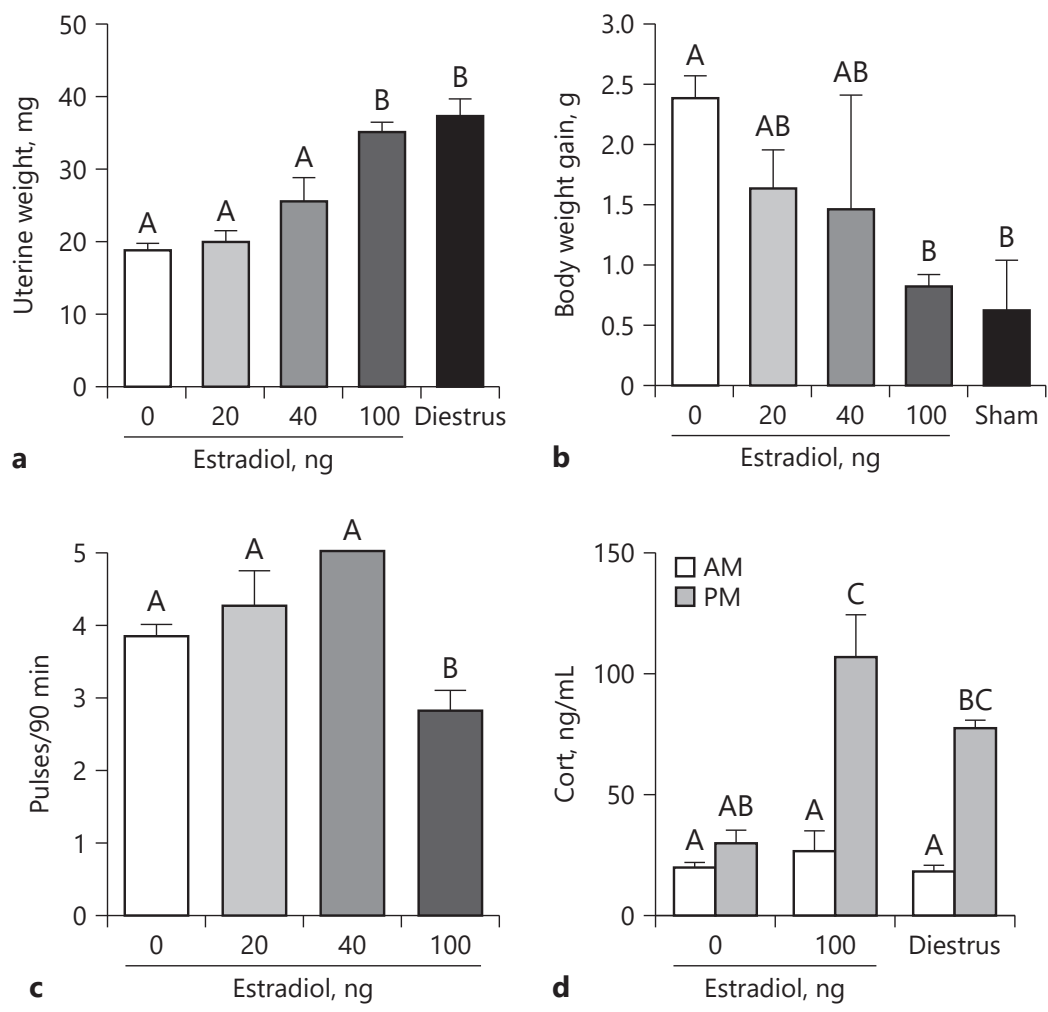

Experiment 2: Does Estradiol Enable Chronic

Corticosterone to Inhibit Pulsatile LH Secretion?

$O V X+E$ treatment. Mice were OVX and implanted subcutaneously with either an implant containing $0 \mathrm{ng}$ estradiol (oil control) or an implant containing 20, 40, or $100 \mathrm{ng}$ estradiol. Approximately 10 days after OVX and estradiol replacement, uterine weight, weight gain following OVX, and LH pulse frequency were examined to document and determine the effectiveness of each estradiol treatment. In the absence of estradiol replacement, average uterine weight was $18.9 \pm 1.0 \mathrm{mg}$, which did not significantly differ from mice implanted with 20 ng estradiol or $40 \mathrm{ng}$ estradiol (Fig. $3 \mathrm{a}, p>0.05$ ). In contrast, $100 \mathrm{ng}$ estradiol significantly increased the uterine weight compared to values in oil control animals (Fig. 3a, $35 \pm 1.3 \mathrm{mg}, 0$ vs. $100 \mathrm{ng}$ estradiol, $p<0.05$ ), and values did not significantly differ from uterine weight values obtained from sham OVX controls sampled in diestrus (Fig. 3a, $37.3 \pm 2.5 \mathrm{mg}, p>0.05$ ). Although all animals gained weight during the 10 days period from OVX, the body weight change in animals treated with $100 \mathrm{ng}$ estradiol was not different from the increase in body weight in sham OVX controls, indicat- ing that treatment with $100 \mathrm{ng}$ estradiol was sufficient to prevent the weight gain that resulted from OVX (Fig. 3b, $2.4 \pm 0.2$ vs. $0.8 \pm 0.1$ g, 0 vs. $100 \mathrm{ng} \mathrm{E2,} p<0.05$ ). $\mathrm{LH}$ pulse frequency in response to 20 or $40 \mathrm{ng}$ estradiol did not differ from the frequency in control animals (Fig. 3c, $p>0.05$ ); yet, replacement with $100 \mathrm{ng}$ estradiol significantly slowed LH pulse frequency (Fig. 3c, 0 vs. $100 \mathrm{ng} \mathrm{E2,} p<0.05)$. Although not significant, treatment with $100 \mathrm{ng}$ estradiol lowered the mean LH and elicited an increase in pulse amplitude ( 0 vs. $100 \mathrm{ng}$ E2, $p<0.1$; online suppl. Table 2). Interestingly, treatment with $100 \mathrm{ng}$ estradiol also restored an aspect of hypothalamic-pituitary-adrenal axis activity that dissipates when estradiol is removed, as indicated by elevated evening corticosterone that was not significantly different from diestrus control females (Fig. 3d).

Figure 4 shows representative $\mathrm{LH}$ pulse profiles during the 2 periods of frequent tail-tip blood sampling collected from OVX + E mice prior to and $48 \mathrm{~h}$ following implantation with cholesterol (Fig. 4a, b) or corticosterone (Fig. 4c-f). In animals treated with cholesterol, mean LH averaged $3.2 \mathrm{ng} / \mathrm{mL}$, pulse frequency averaged 2.7 pulses $/ 90 \mathrm{~min}$, and pulse amplitude averaged $2.8 \mathrm{ng} / \mathrm{mL}$ in the 

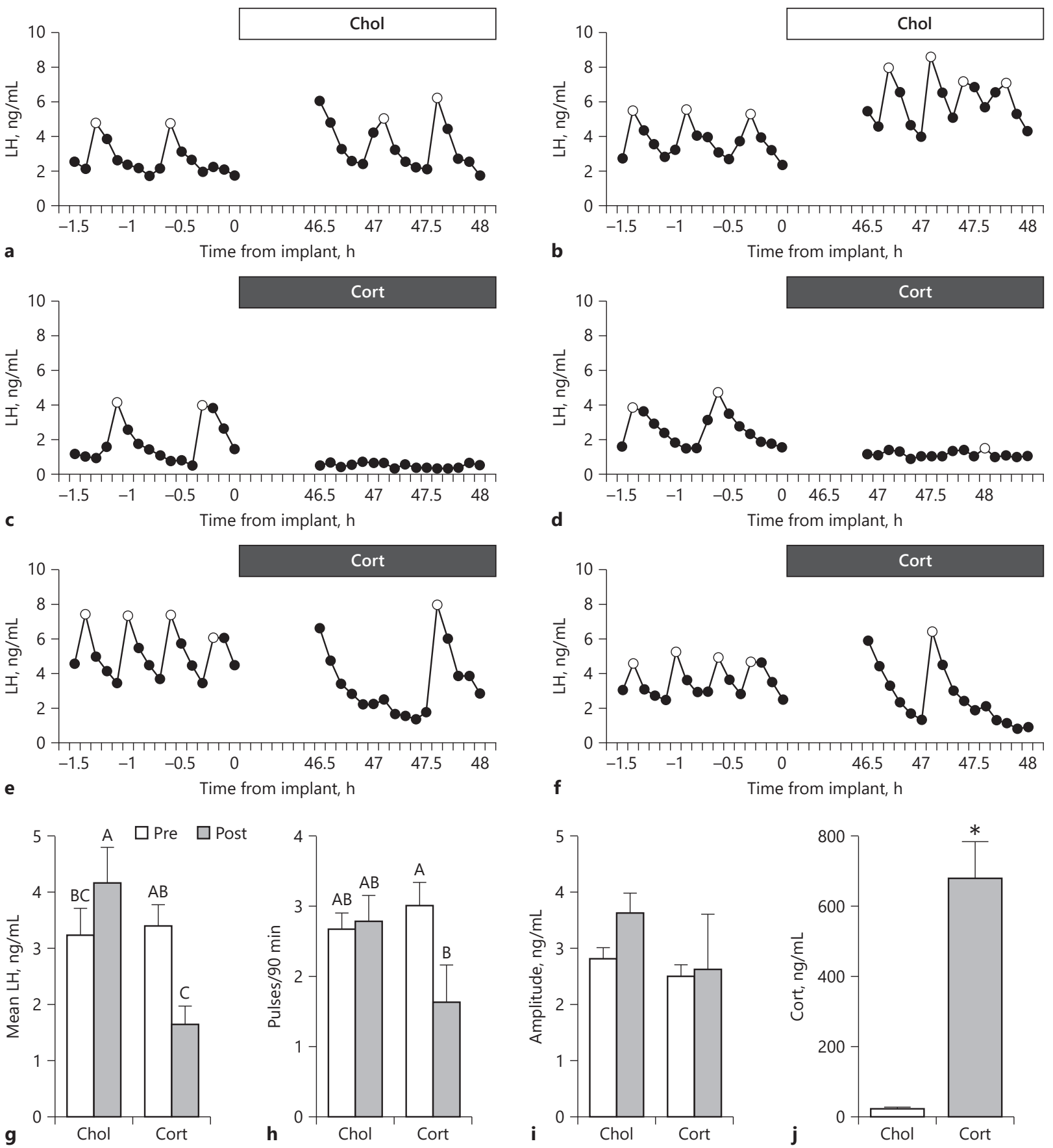

Fig. 4. Chronic corticosterone suppresses LH pulse frequency only in OVX + E mice. Patterns of pulsatile LH secretion in representative OVX + E mice, either implanted with cholesterol (a, b, chol) or corticosterone (c-f, cort). LH pulses are identified by open circles. Values (mean \pm SEM) for mean LH $(\mathbf{g})$, pulse frequency $(\mathbf{h})$, and pulse amplitude (i) were compared across time (Pre, white

bars vs. Post, grey bars) in each treatment group ( $n=8-9$ mice/ group). Unique letters signify significant differences between values $(p<0.05)$. j Serum corticosterone concentrations (mean \pm SEM) in mice prior to the serial sampling which occurred 2 days following implantation ( $n=13$ /group). ${ }^{*}$ Effect of treatment $(p<$ 0.05). LH, luteinizing hormone. 

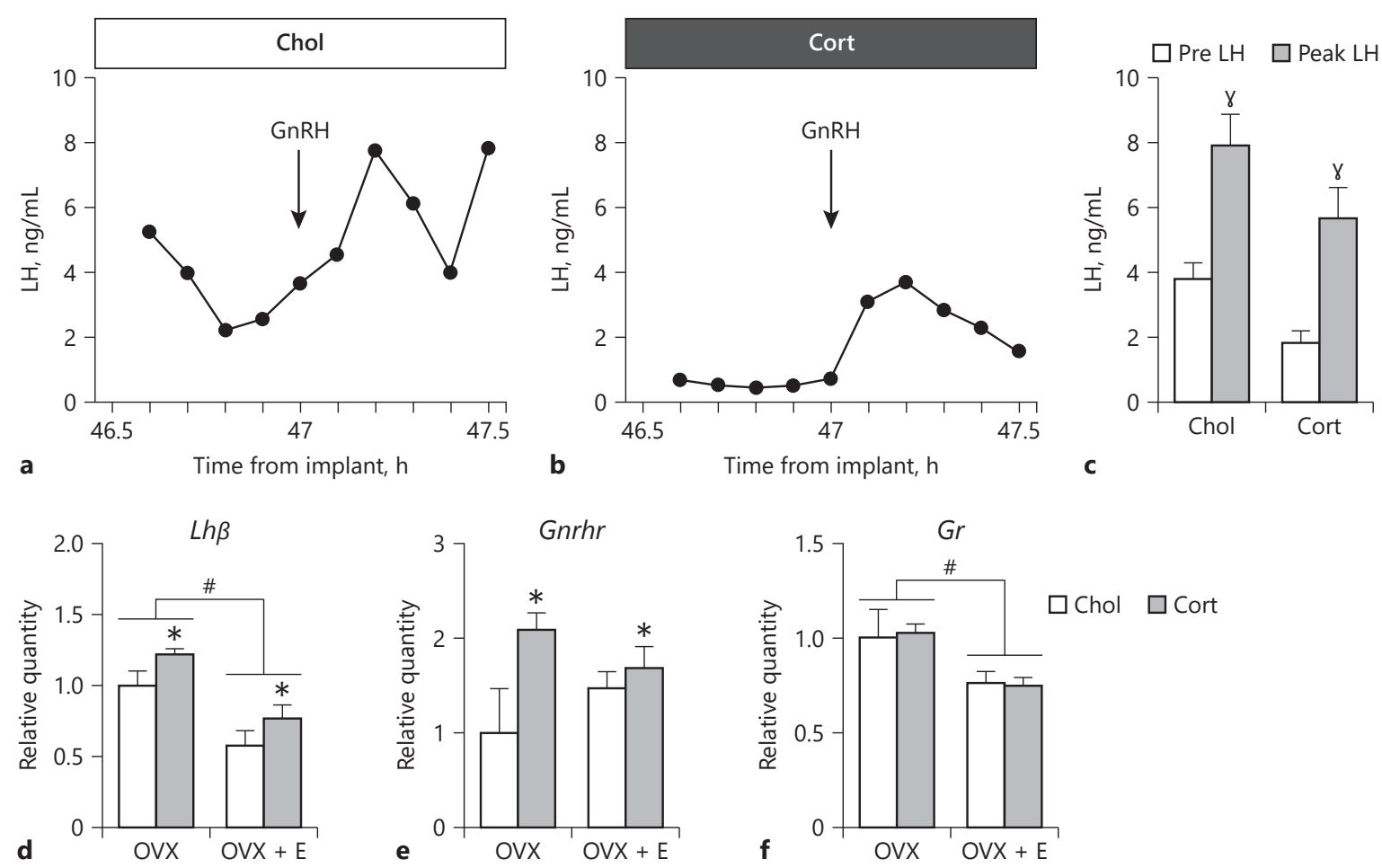

Fig. 5. Chronic corticosterone does not impair pituitary responsiveness. Representative $\mathrm{LH}$ responses to GnRH in OVX + E mice treated with cholesterol (a, chol) or corticosterone (b, cort) and $800 \mathrm{ng} / \mathrm{kg}$ of GnRH (ip) at time 0 . c Mean ( \pm SEM) LH at time 0 (Pre LH) and in response to GnRH (Peak LH). $\gamma, p<0.05$, effect of time. Analysis of (d) $L h \beta$, (e) Gnrhr, and (f) Gr expression in indi-

pre-implant period; values for each $\mathrm{LH}$ characteristic did not significantly differ during the pre-implant period between corticosterone- and cholesterol-treated controls (Fig. 4g-i, chol pre vs. cort pre, $p>0.05$ ). During the postimplant period in animals treated with cholesterol, mean LH values were significantly elevated while frequency and amplitude were both unchanged compared to pre values. In contrast, corticosterone significantly reduced mean LH by $51.7 \%$ and decreased LH pulse frequency by $45.8 \%$ across the 2 sampling windows (Fig. $4 \mathrm{~g}$, h, cort, pre vs. post, $p<0.05$ ). Notably, individual LH responses during treatment with corticosterone were variable: in 2 animals, no pulses were identified (Fig. 4c): in 4 animals, low amplitude pulses were identified (0.4-1.7 ng/mL, Fig. $4 \mathrm{~d})$; and in 2 animals, high amplitude pulses were identified (5.1-6.6 ng/mL, Fig. 4e, f). Again, corticosterone levels were significantly elevated by the corticosterone treatment (Fig. 4 j, chol vs. cort, $p<0.05$ ).

CORT Requires Estradiol to Slow LH

Pulse Frequency vidual pituitary glands collected from OVX or OVX + E mice treated with cholesterol (white bars) or corticosterone (grey bars). No significant estradiol $\times$ treatment interactions were identified. ${ }^{*}$ Effect of estradiol; * effect of corticosterone, $p<0.05$. LH, luteinizing hormone; OVX, ovariectomized; GnRH, gonadotropin-releasing hormone.

\section{Experiment 3: Does Estradiol Enable Chronic} Corticosterone-Induced Suppression of Gonadotrope

Responsiveness to GnRH or Pituitary Gene

\section{Expression?}

We tested the hypothesis that a suppression in gonadotrope cell activity contributes to decreased LH during chronic corticosterone. Representative profiles of LH in tail-tip blood, collected prior to and following an injection of GnRH, from OVX + E mice either implanted with cholesterol or corticosterone are shown (Fig. 5a, b). Prior to injection, LH levels averaged $3.7 \mathrm{ng} / \mathrm{m}$ in the control group and $1.8 \mathrm{ng} / \mathrm{mL}$ in the corticosterone group (Fig. $5 \mathrm{c}$, pre). In response to $\mathrm{GnRH}$, peak LH levels reached an average value of $7.9 \mathrm{ng} / \mathrm{mL}$ in mice treated with cholesterol compared to $5.6 \mathrm{ng} / \mathrm{mL}$ in mice treated with corticosterone (Fig. $5 c, p>0.05$ ); the amplitude of the LH response to $\mathrm{GnRH}$ did not significantly differ between treatments $(4.1 \pm 0.6$ vs. $3.8 \pm 0.9 \mathrm{ng} / \mathrm{mL}$, chol vs. cort, $p>0.05)$. 


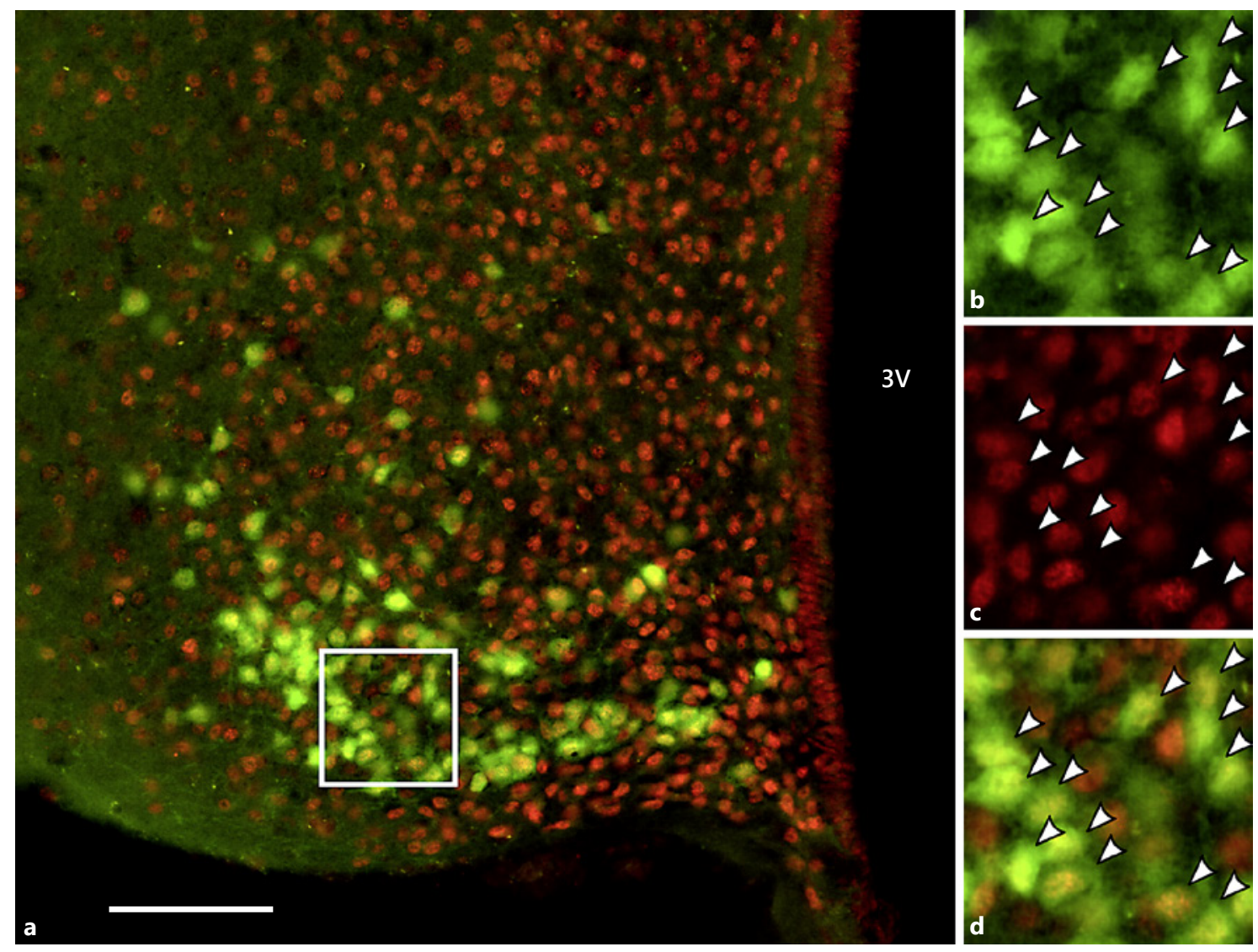

Fig. 6. GR is expressed in Kiss1 cells of the mediobasal hypothalamus. Representative photomicrograph of duallabeled Kiss1CreGFP and GR cells in the middle arcuate (a). White box indicates location of zoomed panels depicting staining for GFP (b, green), GR (c, red), and the merged image (d). White arrowheads indicate dual-labeled Kiss1CreGFP-GR cells. Scale bar equals $40 \mu \mathrm{m}$.

Pituitaries were collected from animals treated with chronic corticosterone or cholesterol in the absence or presence of estradiol. Although significant effects of corticosterone or estradiol treatment were identified, no significant interactions between these 2 factors were observed. For example, $L h \beta$ was suppressed by estradiol in animals treated with or without corticosterone and increased by corticosterone regardless of estradiol treatment (Fig. 5d, $p<0.05$ ). Gnrhr also showed a significant increase in response to corticosterone regardless of estradiol treatment (Fig. 5e). Gr expression was suppressed by estradiol in both groups (Fig. 5f).

\section{Experiment 4: Is GR Expressed in KNDy Neurons?}

To determine if corticosterone can act directly on KNDy cells, we performed IHC for GR using brain tissue from Kiss1CreGFP females treated with or without estradiol. The majority of GFP-labeled Kiss1 neurons throughout the arcuate hypothalamus, in either OVX or OVX + E mice, contained clear nuclear labeling for GR (Fig. 6). Estradiol treatment did not significantly alter the percentage of Kiss 1 neurons that contained GR, except for a modest increase in the rostral arcuate (Table 2).

\section{Experiment 5: Does Chronic Corticosterone Inhibit} KNDy Gene Expression or KNDy Neuron Activity?

Brains were collected from OVX or OVX + E mice following treatment with chronic corticosterone or cholesterol and gene expression for KNDy peptides and receptors were analyzed in micro punches of the arcuate hypothalamus (Fig. 7). Both Kiss1 and Tac2 were downregulated by estradiol $(p<0.05)$, confirming the effectiveness of the estradiol treatment; however, neither Kiss 1 nor Tac2 were further suppressed by corticosterone in OVX + E mice. In contrast, corticosterone decreased 


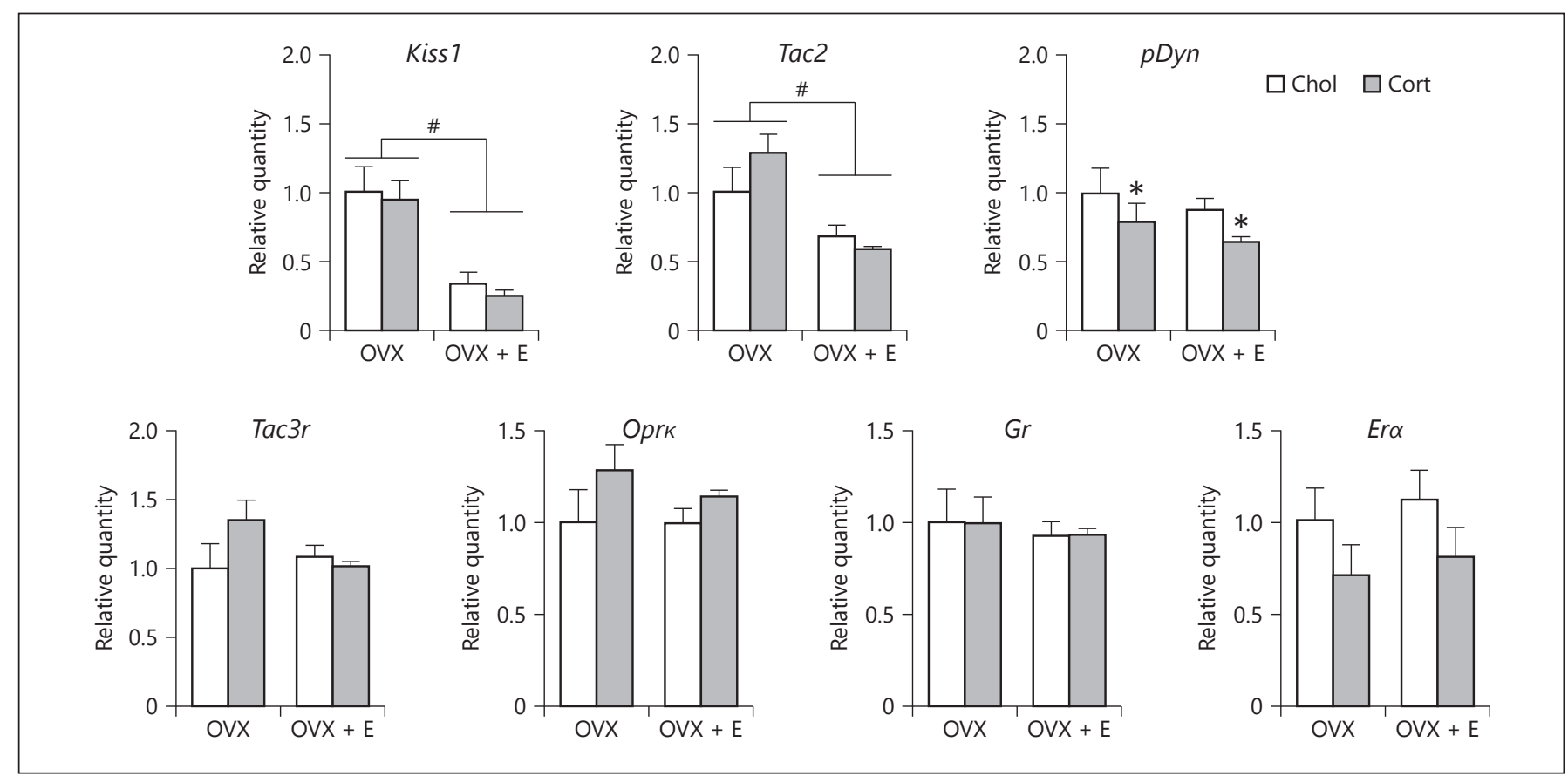

Fig. 7. Chronic corticosterone does not suppress arcuate KNDyassociated gene expression. Quantitative polymerase chain reaction analysis of Kiss1, Tac2, pDyn, Tac3r, Oprk, Gr, and Er $\alpha$ gene expression in arcuate micropunches collected from OVX or OVX + E mice and treated with cholesterol (white bars, chol) or corti-

pDyn, the gene encoding dynorphin, regardless of estradiol treatment (Fig. 7, $p<0.05$ ). Neither the mRNA expression of receptors for neurokinin B or dynorphin, $T a c 3 r$ and $O p r \kappa$, respectively, nor Gr or Er $\alpha$ were altered by corticosterone or estradiol (Fig. 7, $p>0.05$ ).

Using Kiss1hrGFP females, we investigated whether corticosterone-induced inhibition of pulsatile LH was associated with changes in Kiss 1 neuronal activity. Figure 8 shows representative photomicrographs of nuclear c-Fos within GFP-labeled Kiss 1 cells in a Kiss1hrGFP $\mathrm{OVX}+\mathrm{E}$ female treated with either cholesterol (Fig. 8ac) or corticosterone (Fig. 8d-f). A robust population of Kiss1 cells were identified in the rostral, middle, and caudal regions of the arcuate nucleus using this mouse model, in which GFP expression is under the control of the Kiss1 promoter. Although treatment with estradiol did not alter the total number of Kiss1hrGFP cells detected (Fig. 8g-i) according to our methods, we did observe a 70\% suppression in GFP intensity/cell in OVX + $\mathrm{E}$ females compared to OVX animals across all 3 regions of the arcuate hypothalamus. This may indicate estradiol-dependent regulation of the Kiss 1 population in Kiss1hrGFP mice. Using this mouse model, we deter-

CORT Requires Estradiol to Slow LH

Pulse Frequency costerone (grey bars, cort). No significant estradiol $\times$ treatment interactions were identified. * Effect of estradiol; * effect of corticosterone, $p<0.05$. All data represented as mean \pm SEM. OVX, ovariectomized; ERa, estradiol receptor alpha.

Table 2. IHC for GFP and GR

\begin{tabular}{lll}
\hline & OVX & OVX $+\mathrm{E}$ \\
\hline \# GFP cells/hemi-section & & \\
$\quad$ rARC & $26.4 \pm 8.0$ & $24.2 \pm 9.2$ \\
mARC & $69.4 \pm 9.5$ & $54.9 \pm 8.0$ \\
cARC & $54.1 \pm 9.4$ & $74.2 \pm 14.8$ \\
\% GFP cells with GR & & \\
rARC & $86.0 \pm 1.3^{\mathrm{A}}$ & $97.4 \pm 1.3^{\mathrm{B}}$ \\
mARC & $93.3 \pm 0.7$ & $92.7 \pm 3.1$ \\
cARC & $96.2 \pm 2.2$ & $89.3 \pm 4.0$ \\
\hline
\end{tabular}

Values are mean \pm SEM. Regions of the arcuate hypothalamus are referred to as: rostral (r), middle (m), and caudal (c).

Values with unique superscripts are significantly different between OVX and OVX + E $(p<0.05)$.

IHC, immunohistochemistry; OVX, ovariectomized; GFP, green fluorescent protein; GR, glucocorticoid receptor.

mined that the number of Kiss 1 hrGFP cells detected was not changed by chronic corticosterone in either OVX or OVX + E females (Fig. 8g-i); under these conditions, GFP intensity/cell was not altered by chronic 
Fig. 8. Corticosterone-induced suppression of Kiss 1 neuronal activation requires estradiol. Representative photomicrographs depicting staining for Kiss1hrGFP (a, d, green), c-Fos (b, e, purple), and duallabeled Kiss $1 / \mathrm{c}$-Fos cells $(\mathbf{c}, \mathbf{f})$ in the middle arcuate of OVX + E mice treated with cholesterol $(\mathbf{a}-\mathbf{c})$ or corticosterone $(\mathbf{d}-\mathbf{f})$. White box indicates location of zoomed panels. White arrowheads indicate duallabeled Kiss1/c-Fos cells. Scale bar equals $40 \mu \mathrm{m}$. Number of Kiss1 cells $(\mathbf{g}-\mathbf{i})$ and percent of Kiss1 cells with c-Fos (j-I) per hemi-section of OVX or OVX + E mice treated with cholesterol (white bars, Chol) or corticosterone (grey bars, Cort). Regions of the arcuate hypothalamus are referred to as: rostral (r), middle (m), and caudal (c). Back-transformed mean $( \pm$ SEM) values are displayed. Unique letters signify significant differences between values $(p<0.05)$. GFP, green fluorescent protein; OVX, ovariectomized.
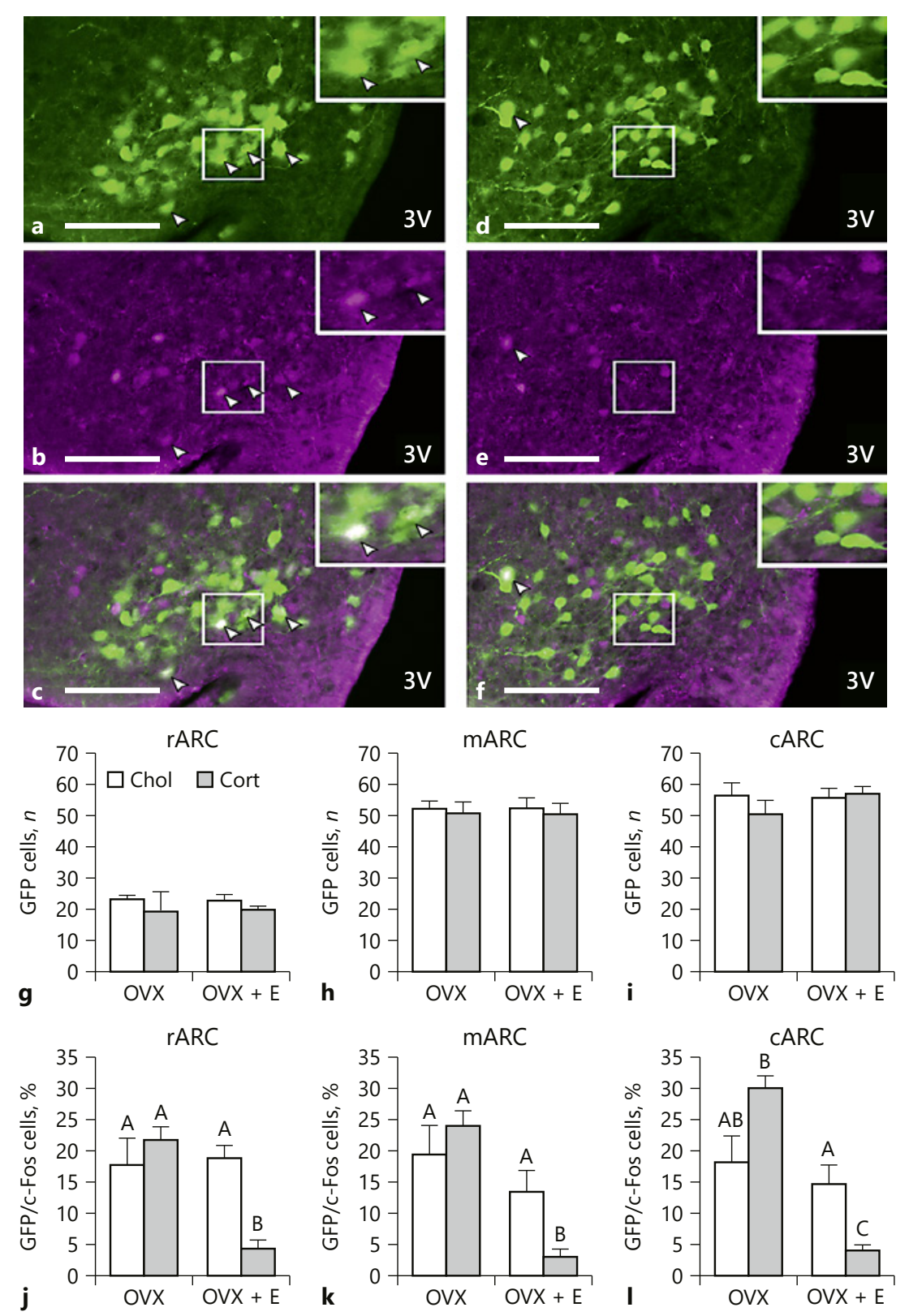

corticosterone. Approximately 17-20\% GFP-labeled Kiss1 cells contained c-Fos in OVX mice treated with cholesterol; in OVX mice, corticosterone did not significantly change the co-expression in any region (Fig. 8j-1). In contrast, corticosterone induced a robust suppression in the percent of Kiss1 cells expressing cFos in OVX $+\mathrm{E}$ females compared to controls $(p<0.05$, $72-78 \%$ suppression); the suppression was present in all 3 regions of the arcuate nucleus.

\section{Discussion/Conclusion}

The aim of the present study was to test the hypothesis that a chronic elevation in glucocorticoids can disrupt pulsatile LH secretion in female mice. This investigation was based on our prior finding that a chronic elevation of corticosterone impairs ovarian cyclicity in mice by preventing progression through the follicular phase [4]. We demonstrate that chronic corticosterone has no effect on 
LH secretion in OVX mice; however, in the presence of a physiologic level of estradiol, corticosterone is able to reduce LH secretion by slowing LH pulse frequency. The suppression in LH is not associated with reduced $\operatorname{Lh} \beta$ or Gnrhr expression or impaired pituitary responsiveness to $\mathrm{GnRH}$, suggesting corticosterone is acting upstream of the gonadotrope cell. As for a potential neuronal cell type mediating the suppression of pulsatile $\mathrm{LH}$ secretion, this study shows that a majority of arcuate Kiss 1 neurons in the female mouse contain GR and that corticosterone decreases neuronal activation of this population of Kiss 1 cells, as measured by c-Fos, in females treated with estradiol. Taken together, these data demonstrate that estradiol is necessary for corticosterone to impair the frequency of LH pulses in female mice, potentially via a direct action upon arcuate kisspeptin neurons.

A pertinent question raised by these findings is whether chronic corticosterone is acting directly or indirectly on arcuate kisspeptin cells to inhibit LH. Arcuate kisspeptin cells contain ERa [28], and the current study reveals that $\sim 90 \%$ of arcuate Kiss1 neurons contain GR. Together, these observations identify the KNDy cell as a potential site whereby estradiol could enable corticosterone to impair pulsatile $\mathrm{LH}$ secretion. Our results in the mouse are consistent with studies in sheep. Considering that nearly all arcuate dynorphin cells co-express kisspeptin in ewes [20], and that $80 \%$ of dynorphin cells are co-localized with GR [29], we can infer that a majority of arcuate kisspeptin neurons in the sheep contain GR. Interestingly, the female rat may demonstrate a species difference in both GR co-localization and sensitivity to corticosterone-induced LH suppression. Evidence that $<3 \%$ of arcuate kisspeptin neurons express GR in diestrus female rats [45] offers a potential explanation for why OVX $+\mathrm{E}$ female rats did not demonstrate a disruption in $\mathrm{LH}$ pulsatile secretion following either acute or chronic corticosterone [46]. Takumi et al. [45] did observe that a majority of kisspeptin-containing cells within the anteroventral periventricular nucleus and periventricular nucleus continuum were found to express GR in female rats administered colchicine. Although interesting to consider a potential species difference, a direct comparison cannot be made as the gonad status of the animals and GR antibody employed were also different. These findings do clearly show that corticosterone has the potential to act on KNDy cells, at least in the mouse, and provide the foundation for future studies utilizing neuronal-specific GR knockouts to elucidate whether chronic corticosterone is acting directly on Kiss1 neurons or via afferent projections to this cell population.

CORT Requires Estradiol to Slow LH

Pulse Frequency
Another question raised by these findings is the cellular mechanism whereby estradiol enables the suppression of pulse frequency by chronic corticosterone. A role for estradiol was demonstrated by previous work in female sheep which showed that elevated glucocorticoids decreased LH pulse frequency, also in an ovarian steroiddependent manner, via a reduction in the frequency of GnRH pulses $[6,16]$. We extend this observation by demonstrating that chronic corticosterone markedly impairs Kiss1 neuronal activity throughout the arcuate nucleus in an estradiol-dependent manner. Based on our current understanding that these cells function as the $\mathrm{GnRH}$ pulse generator, we hypothesized that both estradiol and corticosterone could induce changes directly within this population of cells to influence the pulse frequency. We assessed levels of GR and determined that estradiol does not upregulate $\mathrm{Gr}$ expression nor increase GR co-localization in kisspeptin cells. In lieu of a change in GR expression, we explored transcriptional regulation by estradiol and corticosterone. Estradiol caused a robust reduction in Tac2 and Kiss1, lowering levels by 40 and 70\%, respectively, in OVX + E females; however, levels were not further reduced by corticosterone treatment.

Dynorphin is another interesting candidate that could mediate corticosterone-induced suppression of KNDy activity. Indeed, blocking dynorphin action with a kappaopioid receptor antagonist elicits an increase in LH pulse frequency [23,47] which is associated with increased multi-unit activity in the mediobasal hypothalamus [23]. We evaluated dynorphin expression in animals treated with chronic corticosterone and estradiol, based on observations that ER and GR can alter transcriptional activity via crosstalk at promoter response elements [48, 49], including at the dynorphin promoter leading to increased dynorphin expression [50]. However, the current study showed a decrease in dynorphin mRNA expression in response to corticosterone, suggesting that upregulation of this inhibitory peptide is not likely to underlie the suppression in LH here. Interestingly, a few pieces of evidence support an alternate mechanism, whereby estradiol enhances the inhibitory action of dynorphin on the $\mathrm{GnRH}$ pulse generator. Electrophysiological recordings of KNDy cells in male mice showed that in vivo treatment with estradiol enhanced the inhibitory effect of dynorphin on KNDy neuron firing [51]. Furthermore, work in the female rat demonstrates that central delivery of a kappa-opioid receptor antagonist has no effect on the pulse generator in OVX animals, but prevents the negative feedback effect of estradiol on LH pulses in OVX + E females [52]. Future work is needed to test the possibility

Neuroendocrinology 2020;110:501-516 DOI: $10.1159 / 000502978$ 
that estradiol enables chronic corticosterone to inhibit KNDy cells via a dynorphin-dependent pathway.

A couple of comments are warranted regarding the estradiol and corticosterone treatments employed in the current study. First, the estradiol replacement dose utilized here recapitulates a host of normal physiological responses. For example, this dose restores peak serum corticosterone and prevents increased weight gain induced by OVX. Based on uterine weight, which is a simple and effective correlate of circulating estradiol [53], this estradiol dose mimics a diestrus level. Importantly for our studies, while this level of estradiol slows pulse frequency, the frequency and amplitude of LH pulsatile secretion is robust, and the detection of pulses is reliable as compared to published reports of $\mathrm{LH}$ profiles in diestrus mice that may be slower and lower in amplitude [54]. Therefore, we utilized this OVX + E model, which normalized estradiol levels across animals and removed other factors influenced by the ovarian cycle, to directly test the effect of estradiol on the $\mathrm{LH}$ response during a chronic elevation of corticosterone. Although the magnitude of the increment of corticosterone is physiologic [4, 35], the duration of this elevation exceeds that of an acute stress-induced increase, which would be lowered over time due to negative feedback. Whether an acute rise in corticosterone can also inhibit $\mathrm{LH}$ via a suppression in frequency in the female mouse remains to be tested. However, findings in OVX sheep that an acute increase in cortisol inhibits LH pulse amplitude via a pituitary mechanism without altering frequency [7] points to a potential role of glucocorticoid duration underlying LH suppression, in addition to a role of estradiol. Interestingly, we have shown that acute psychosocial restraint stress dramatically reduces LH pulse frequency in OVX mice, demonstrating that estradiol is not necessary for the suppression in frequency in response to this stress type [33]. Therefore, acute stressors may act via pathways independent of corticosterone or corticosterone may not require estradiol to inhibit LH pulses when administered acutely.

In summary, we utilized a female mouse model that allows for reliable detection of $\mathrm{LH}$ pulses to demonstrate that estradiol is necessary for chronic corticosterone to impair the frequency of LH pulses. We show that arcuate kisspeptin cells contain GR and demonstrate reduced kisspeptin neuronal activation in response to chronic corticosterone via an estradiol-dependent mechanism. Future studies are warranted to investigate acute elevations in glucocorticoids and whether a direct action by this stress hormone upon arcuate kisspeptin neurons mediates altered gonadotropin secretion commonly associated with stress $[55,56]$.

\section{Acknowledgements}

The authors wish to thank Dr. Carol Elias (University of Michigan) for her generous gift of the Kiss1CreGFP and Kiss1hrGFP mouse lines. We thank the Nikon Imaging Center at UC San Diego for access to microscopes and technical assistance with imaging.

\section{Statement of Ethics}

The authors have no ethical conflicts to disclose.

\section{Disclosure Statement}

The authors have no conflicts of interest to declare.

\section{Funding Sources}

This work was supported by NIH grant R01 HD086100, NSF grant IOS-1457226 and the UCSD Health Sciences Senate. R.B.M. was supported by NIH grant F32 HD096811 and T32 HD007203. K.T. was partially supported by an Endocrine Society Summer Research Fellowship; K.T. and C.I.S. were partially supported by UCSD Eureka! Undergraduate Research Scholarships. Serum hormone assays were performed by The University of Virginia Ligand Assay Core Laboratory, which is supported through National Institute of Child Health and Human Development Grant P50 HD028934.

\section{Author Contributions}

M.J.K.: designed and performed the experiments, interpreted and analyzed results, and contributed to the writing of the manuscript. R.B.M.: helped with IHC studies, interpreted results, and contributed to the writing of the manuscript. K.T.: contributed to acquisition of animal tissue for experiments, interpretation of results, and participated in critical discussions during manuscript revision. C.I.S.: conducted preliminary GR/Kiss1 IHC studies, contributed to the interpretation of results, and participated in critical discussions during manuscript revision. K.M.B.: designed the experiments, interpreted the results, and wrote the manuscript. All authors edited, reviewed and approved the current manuscript.

References

Neuroendocrinology 2020;110:501-516 DOI: $10.1159 / 000502978$
1 Briski KP, Vogel KL. Role of endogenous opioid peptides in central glucocorticoid receptor (GR)-induced decreases in circulating LH in the male rat. Neuropeptides. 1995 Mar; 28(3):175-81.

2 Breen KM, Oakley AE, Pytiak AV, Tilbrook AJ, Wagenmaker ER, Karsch FJ. Does cortisol acting via the type II glucocorticoid receptor mediate suppression of pulsatile luteinizing hormone secretion in response to psychosocial stress? Endocrinology. 2007 Apr;148(4): 1882-90. 
3 Briski KP, Sylvester PW. Antagonism of type II, but not type I glucocorticoid receptors results in elevated basal luteinizing hormone release in male rats. Neuroendocrinology. 1994 Dec;60(6):601-8.

4 Luo E, Stephens SB, Chaing S, Munaganuru N, Kauffman AS, Breen KM. Corticosterone blocks ovarian cyclicity and the LH surge via decreased kisspeptin neuron activation in female mice. Endocrinology. 2016 Mar;157(3): 1187-99.

5 Saketos M, Sharma N, Santoro NF. Suppression of the hypothalamic-pituitary-ovarian axis in normal women by glucocorticoids. Biol Reprod. 1993 Dec;49(6):1270-6.

6 Breen KM, Billings HJ, Wagenmaker ER, Wessinger EW, Karsch FJ. Endocrine basis for disruptive effects of cortisol on preovulatory events. Endocrinology. 2005 Apr;146(4): 2107-15.

7 Breen KM, Karsch FJ. Does cortisol inhibit pulsatile luteinizing hormone secretion at the hypothalamic or pituitary level? Endocrinology. $2004 \mathrm{Feb} ; 145(2): 692-8$.

8 Chantaraprateep P, Thibier M. Effects of dexamethasone on the responses of luteinizing hormone and testosterone to two injections of luteinizing hormone releasing hormone in young postpubertal bulls. J Endocrinol. 1978 Jun;77(3):389-95.

9 Melis GB, Mais V, Gambacciani M, Paoletti AM, Antinori D, Fioretti P. Dexamethasone reduces the postcastration gonadotropin rise in women. J Clin Endocrinol Metab. 1987 Aug;65(2):237-41.

10 Pearce GP, Paterson AM, Hughes PE. Effect of short-term elevations in plasma cortisol concentration on LH secretion in prepubertal gilts. J Reprod Fertil. 1988 May;83(1):413-8.

11 Li PS, Wagner WC. In vivo and in vitro studies on the effect of adrenocorticotropic hormone or cortisol on the pituitary response to gonadotropin releasing hormone. Biol Reprod. 1983 Aug;29(1):25-37.

12 Suter DE, Orosz G. Effect of treatment with cortisol in vivo on secretion of gonadotropins in vitro. Biol Reprod. 1989 Dec;41(6):1091-6.

13 Suter DE, Schwartz NB, Ringstrom SJ. Dual role of glucocorticoids in regulation of pituitary content and secretion of gonadotropins. Am J Physiol. 1988 May;254(5 Pt 1):E595-600.

14 Ringstrom SJ, Schwartz NB. Cortisol suppresses the $\mathrm{LH}$, but not the $\mathrm{FSH}$, response to gonadotropin-releasing hormone after orchidectomy. Endocrinology. 1985 Jan;116(1):472-4.

15 Dubey AK, Plant TM. A suppression of gonadotropin secretion by cortisol in castrated male rhesus monkeys (Macaca mulatta) mediated by the interruption of hypothalamic gonadotropin-releasing hormone release. Biol Reprod. 1985 Sep;33(2):423-31.

16 Oakley AE, Breen KM, Clarke IJ, Karsch FJ, Wagenmaker ER, Tilbrook AJ. Cortisol reduces gonadotropin-releasing hormone pulse frequency in follicular phase ewes: influence of ovarian steroids. Endocrinology. 2009 Jan; 150(1):341-9.
17 Burger LL, Vanacker C, Phumsatitpong C, Wagenmaker ER, Wang L, Olson DP, et al. Identification of genes enriched in $\mathrm{GnRH}$ neurons by translating ribosome affinity purification and RNAseq in mice. Endocrinology. 2018 Apr;159(4):1922-40.

18 Dufourny L, Skinner DC. Type II glucocorticoid receptors in the ovine hypothalamus: distribution, influence of estrogen and absence of co-localization with GnRH. Brain Res. 2002 Aug;946(1):79-86.

19 Lehman MN, Karsch FJ. Do gonadotropinreleasing hormone, tyrosine hydroxylase-, and beta-endorphin-immunoreactive neurons contain estrogen receptors? A doublelabel immunocytochemical study in the Suffolk ewe. Endocrinology. 1993 Aug;133(2): 887-95.

20 Goodman RL, Lehman MN, Smith JT, Coolen LM, de Oliveira CV, Jafarzadehshirazi MR, et al. Kisspeptin neurons in the arcuate nucleus of the ewe express both dynorphin A and neurokinin B. Endocrinology. 2007 Dec;148(12): 5752-60.

21 Navarro VM, Gottsch ML, Chavkin C, Okamura H, Clifton DK, Steiner RA. Regulation of gonadotropin-releasing hormone secretion by kisspeptin/dynorphin/neurokinin B neurons in the arcuate nucleus of the mouse. J Neurosci. 2009 Sep;29(38):11859-66.

22 Ohkura S, Takase K, Matsuyama S, Mogi K, Ichimaru T, Wakabayashi Y, et al. Gonadotrophin-releasing hormone pulse generator activity in the hypothalamus of the goat. J Neuroendocrinol. 2009 Oct;21(10):813-21.

23 Wakabayashi Y, Nakada T, Murata K, Ohkura S, Mogi K, Navarro VM, et al. Neurokinin $\mathrm{B}$ and dynorphin $\mathrm{A}$ in kisspeptin neurons of the arcuate nucleus participate in generation of periodic oscillation of neural activity driving pulsatile gonadotropin-releasing hormone secretion in the goat. J Neurosci. 2010 Feb;30(8):3124-32.

24 Lehman MN, Coolen LM, Goodman RL. Minireview: kisspeptin/neurokinin B/dynorphin (KNDy) cells of the arcuate nucleus: a central node in the control of gonadotropinreleasing hormone secretion. Endocrinology. 2010 Aug;151(8):3479-89.

25 Rance NE, Krajewski SJ, Smith MA, Cholanian M, Dacks PA. Neurokinin B and the hypothalamic regulation of reproduction. Brain Res. 2010 Dec;1364:116-28.

26 Clarkson J, Han SY, Piet R, McLennan T, Kane GM, Ng J, et al. Definition of the hypothalamic GnRH pulse generator in mice. Proc NatlAcadSciUSA.2017Nov;114(47):E1021623.

27 Franceschini I, Lomet D, Cateau M, Delsol G, Tillet Y, Caraty A. Kisspeptin immunoreactive cells of the ovine preoptic area and arcuate nucleus co-express estrogen receptor alpha. Neurosci Lett. 2006 Jul;401(3):225-30.

28 Smith JT, Cunningham MJ, Rissman EF, Clifton DK, Steiner RA. Regulation of Kiss1 gene expression in the brain of the female mouse. Endocrinology. 2005 Sep;146(9):3686-92.
29 Oakely AE. Central inhibitory effects of glucocorticoids on reproductive function: Permissive role of estradiol (Doctor of Philosophy): University of Michigan, 2008, Doctor of Philosophy Dissertation.

30 Cravo RM, Margatho LO, Osborne-Lawrence S, Donato J Jr, Atkin S, Bookout AL, et al. Characterization of Kiss1 neurons using transgenic mouse models. Neuroscience. 2011 Jan;173:37-56.

31 Cravo RM, Frazao R, Perello M, OsborneLawrence S, Williams KW, Zigman JM, et al. Leptin signaling in Kiss1 neurons arises after pubertal development. PLoS One. 2013; 8(3):e58698.

32 McCosh RB, Kreisman MJ, Breen KM. Frequent tail-tip blood sampling in mice for the assessment of pulsatile luteinizing hormone secretion. J Vis Exp. 2018 Jul;(137). https:// doi.org/10.3791/57894.

33 Yang JA, Song CI, Hughes JK, Kreisman MJ, Parra RA, Haisenleder DJ, et al. Acute psychosocial stress inhibits LH pulsatility and Kiss1 neuronal activation in female mice. Endocrinology. 2017 Nov;158(11):3716-23.

34 Meyer JS, Micco DJ, Stephenson BS, Krey LC, McEwen BS. Subcutaneous implantation method for chronic glucocorticoid replacement therapy. Physiol Behav. 1979 May; 22(5):867-70.

35 Breen KM, Thackray VG, Hsu T, Mak-McCully RA, Coss D, Mellon PL. Stress levels of glucocorticoids inhibit LH $\beta$-subunit gene expression in gonadotrope cells. Mol Endocrinol. 2012 Oct;26(10):1716-31.

36 Chen A, Zorrilla E, Smith S, Rousso D, Levy C, Vaughan J, et al. Urocortin 2-deficient mice exhibit gender-specific alterations in circadian hypothalamus-pituitary-adrenal axis and depressive-like behavior. J Neurosci. 2006 May;26(20):5500-10.

37 Franklin KB, Paxinos G. Paxinos and Franklin's The mouse brain in stereotaxic coordinates, Fourth edition. Amsterdam, Academic Press, an imprint of Elsevier, 2013.

38 Livak KJ, Schmittgen TD. Analysis of relative gene expression data using real-time quantitative PCR and the 2(-Delta Delta C(T)) Method. Methods. 2001 Dec;25(4):402-8

39 Harlow E, Lane D. Mounting samples in gelvatol or mowiol. CSH Protoc. 2006 Jun; 2006(1):pii:pdb.prot4461.

40 Lerch JK, Alexander JK, Madalena KM, Motti D, Quach T, Dhamija A, et al. Stress increases peripheral axon growth and regeneration through glucocorticoid receptor-dependent transcriptional programs. eNeuro. 2017 Aug;4(4):4.

41 Navailles S, Zimnisky R, Schmauss C. Expression of glucocorticoid receptor and early growth response gene 1 during postnatal development of two inbred strains of mice exposed to early life stress. Dev Neurosci. 2010 Jul;32(2):139-48.

42 Schindelin J, Arganda-Carreras I, Frise E, Kaynig V, Longair M, Pietzsch T, et al. Fiji: an open-source platform for biological-image analysis. Nat Methods. 2012 Jun;9(7):676-82. 
43 Steyn FJ, Wan Y, Clarkson J, Veldhuis JD, Herbison AE, Chen C. Development of a methodology for and assessment of pulsatile luteinizing hormone secretion in juvenile and adult male mice. Endocrinology. 2013 Dec; 154(12):4939-45.

44 Goodman RL, Karsch FJ. Pulsatile secretion of luteinizing hormone: differential suppression by ovarian steroids. Endocrinology. 1980 Nov; 107(5):1286-90.

45 Takumi K, Iijima N, Higo S, Ozawa H. Immunohistochemical analysis of the colocalization of corticotropin-releasing hormone receptor and glucocorticoid receptor in kisspeptin neurons in the hypothalamus of female rats. Neurosci Lett. 2012 Nov;531(1):40-5.

46 Kinsey-Jones JS, Li XF, Knox AM, Wilkinson ES, Zhu XL, Chaudhary AA, et al. Down-regulation of hypothalamic kisspeptin and its receptor, Kiss1r, mRNA expression is associated with stress-induced suppression of luteinising hormone secretion in the female rat. J Neuroendocrinol. 2009 Jan;21(1):20-9.

47 Goodman RL, Hileman SM, Nestor CC, Porter KL, Connors JM, Hardy SL, et al. Kisspeptin, neurokinin $\mathrm{B}$, and dynorphin act in the arcuate nucleus to control activity of the GnRH pulse generator in ewes. Endocrinology. 2013 Nov; 154(11):4259-69.
48 Vahrenkamp JM, Yang CH, Rodriguez AC, Almomen A, Berrett KC, Trujillo AN, et al. Clinical and genomic crosstalk between glucocorticoid receptor and estrogen receptor a in endometrial cancer. Cell Rep. 2018 Mar; 22(11):2995-3005

49 Karmakar S, Jin Y, Nagaich AK. Interaction of glucocorticoid receptor (GR) with estrogen receptor (ER) $\alpha$ and activator protein 1 (AP1) in dexamethasone-mediated interference of ERa activity. J Biol Chem. 2013 Aug;288(33): 24020-34.

50 Ayrout M, Le Billan F, Grange-Messent V, Mhaouty-Kodja S, Lombès M, Chauvin S. Glucocorticoids stimulate hypothalamic dynorphin expression accounting for stress-induced impairment of $\mathrm{GnRH}$ secretion during preovulatory period. Psychoneuroendocrinology. 2019 Jan;99:47-56.

51 Ruka KA, Burger LL, Moenter SM. Both estrogen and androgen modify the response to activation of neurokinin-3 and $\kappa$-opioid receptors in arcuate kisspeptin neurons from male mice. Endocrinology. 2016 Feb;157(2): $752-63$.
52 Mostari P, Ieda N, Deura C, Minabe S, Yamada S, Uenoyama Y, et al. dynorphin-kappa opioid receptor signaling partly mediates estrogen negative feedback effect on LH pulses in female rats. J Reprod Dev. 2013;59(3):26672.

53 Shim WS, Conaway M, Masamura S, Yue W, Wang JP, Kmar R, et al. Estradiol hypersensitivity and mitogen-activated protein kinase expression in long-term estrogen deprived human breast cancer cells in vivo. Endocrinology. 2000 Jan;141(1):396-405.

54 Czieselsky K, Prescott M, Porteous R, Campos P, Clarkson J, Steyn FJ, et al. Pulse and surge profiles of luteinizing hormone secretion in the mouse. Endocrinology. 2016 Dec; 157(12):4794-802.

55 Fourman LT, Fazeli PK. Neuroendocrine causes of amenorrhea-an update. J Clin Endocrinol Metab. 2015 Mar;100(3):812-24.

56 Akhter S, Marcus M, Kerber RA, Kong M, Taylor KC: The impact of periconceptional maternal stress on fecundability. Ann Epidemiol. 2016 Oct;26(10):710-16.e7. 